\title{
City Development, Natural Resources and Human Impact: The Case of Medellin, Colombia
}

\author{
Michel Hermelin \\ Department of Geology, Universidad EAFIT, Medellin, Colombia. \\ Email: hermelin@eafit.edu.co \\ Received September $9^{\text {th }}, 2013$; revised October $2^{\text {st }}, 2013$; accepted November $14^{\text {th }}, 2013$
}

Copyright (C) 2013 Michel Hermelin. This is an open access article distributed under the Creative Commons Attribution License, which permits unrestricted use, distribution, and reproduction in any medium, provided the original work is properly cited. In accordance of the Creative Commons Attribution License all Copyrights (C) 2013 are reserved for SCIRP and the owner of the intellectual property Michel Hermelin. All Copyright (C) 2013 are guarded by law and by SCIRP as a guardian.

\begin{abstract}
Medellin is a $3.5 \mathrm{M}$ inhabitant city located in an Andean valley in northwestern Colombia. Its initial prosperity was due to agriculture and cattle-raising carried out in the valley itself and sold to the surrounding gold mining fields. The investment of these monies in coffee plantations and industry boosted the city development, accelerated urban growth, and since the middle of twentieth century, relegated food production to surrounding regions, which are also responsible for almost the totality of natural resource supply: water, electricity, food, building and industrial raw materials. Among the problems which will have to be solved in order to reach a sustainable development are relocation of population living in areas exposed to natural risks, improvement of road communications with surrounding regions and of internal public transportation and pollution control.
\end{abstract}

Keywords: Urban Growth; Urban Natural Resources; Colombia

\section{Introduction}

Medellin is a city with $3.5 \mathrm{M}$ inhabitants located in a high Andean valley in north western Colombia with relatively difficult access. The relation between the city growth and its natural resources is examined from a historical standpoint. A detailed analysis of its economic growth is not intended; only a short comparison is made with other Colombian colonial cities to draw some conclusions about Medellin success to become the second city in population of the country. Why was the same fate not that of other urban centers located in much better geographic conditions? How could Medellin prevail when it was only a village surrounded by one of the poorest provinces of Nueva Granada at the end of $18^{\text {th }}$ century? Is it due to the abundance of natural resources? The author, as a geologist, does not pretend to analyze in detail fundamental factors as economy, demography and politics, which have been already examined $[1,2]$, but to trace eventual influences of natural environment on the city development. The building of cities was preceded worldwide by the development of agriculture, which is necessary to feed a large concentration of people and to produce surplus [3]. When the Spaniards reached America, they found only two civilizations: the Aztecs in Mexico and the Incas in Peru. Mayas had already suffered a complete decline. Besides these cases, they found isolated belligerent tribes and slightly more developed cultures, like the Chibchas, who populated the Colombian Oriental Cordillera plateaus. This group has been considered by historians as "state in formation" [4].

\section{Foundation of Cities in Nueva Granada}

Rules edicted by Emperors of Spain Charles V and Philip II for city foundation were quite precise [5] and considered the geometry of the urban center and its population: Indians were not allowed to dwell in Spanish cities, excepting slaves and servants; they were supposed to live in separated villages. Santa Maria de la Antigua del Darien, the first city founded in the Spanish main (1510) [6] was abandoned in favor of Panama (1519), which prospered due its geographical location (Figure 1). Cartagena (1533) was chosen due to its strategic location and became the most important harbor in the continent. Bogota (1538) was founded due to the presence of abundant and organ- 


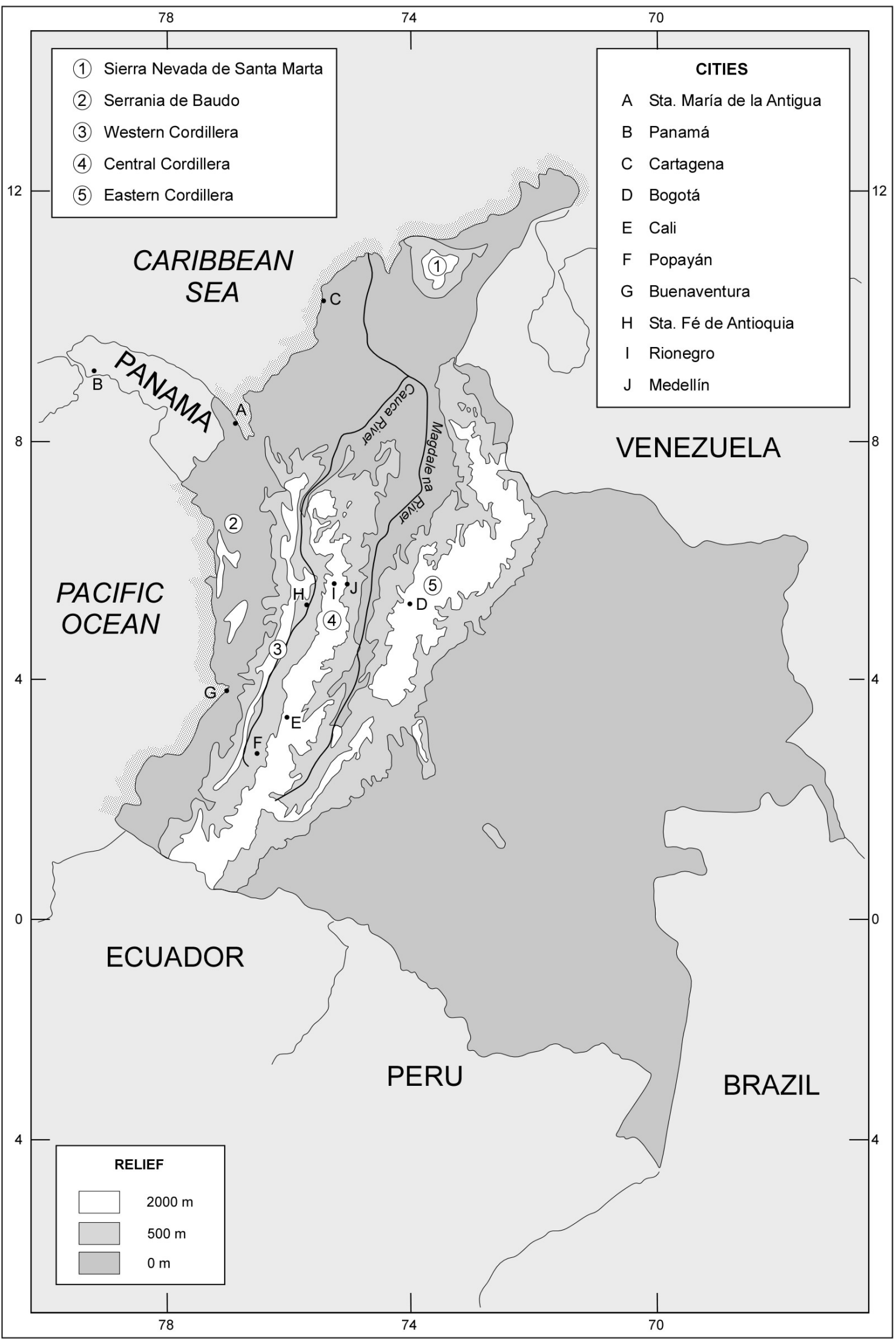

Figure 1. Colombia. 
ized Chibcha population which was subjugated by the Spaniards. [7]. A good climate, rich soils and water in abundance were other assets which ended up transforming this city in the capital of the newly founded kingdom of Nueva Granada. In the southwest, Cali (1536) and Popayan (1537) were important during colonial times, but only Cali became a major city during $20^{\text {th }}$ century, due to its vicinity to the harbor of Buenaventura and the richness of surrounding cultivable land. Despite of the wealth of the gold mines exploited by slave labour owned by Popayan aristocracy, this city declined during $20^{\text {th }}$ century. The province of Antioquia became independent from Popayan in 1575. Two main towns existed there: Santa Fe de Antioquia (1541) and Rionegro (1541), which became a "city" in 1786 . The region relative prosperity came from gold mine exploitation [8], distributed in many districts (Figure 2).

\section{Medellin Natural Setting}

Medellin is located in a broad valley situated in the northern part of the Central Cordillera. The bottom of the

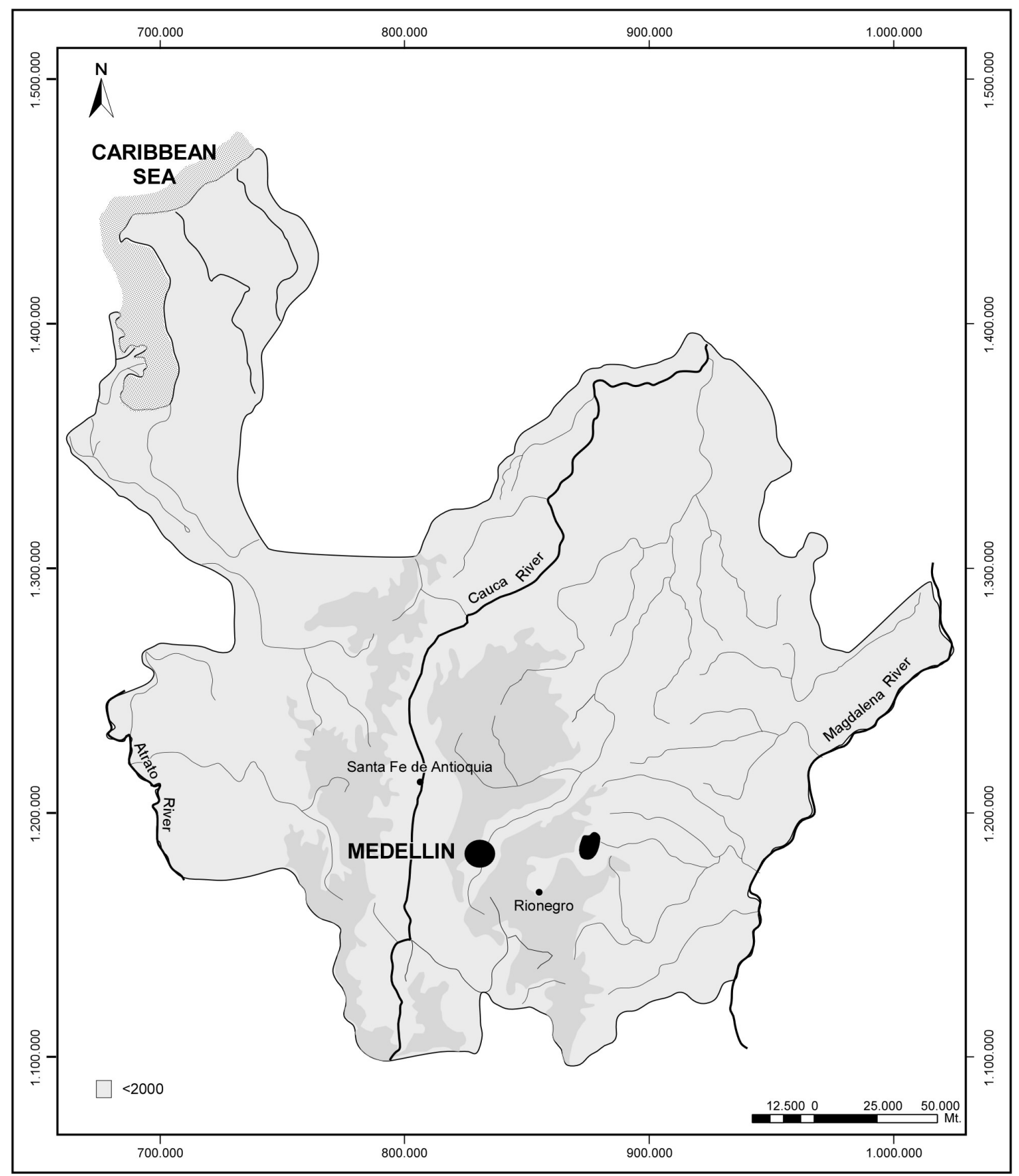

Figure 2. Department of Antioquia, Colombia. 
valley is at about 1500 masl and it is surrounded by little dissected plateaus at 2000 and 2600 masl approximately. The valley maximum width is about $8 \mathrm{~km}$ and it consists of two stretches of $30 \mathrm{~km}$ in north and northeast direction, respectively. The valley bottom is filled by alluvial deposits of irregular thickness and most of its slopes are covered by complex deposits derived from the upper rises [9]. The geology of the valley is complex: Precambrian, Paleozoic and possibly Mesozoic metamorphic rocks, marine diabases, serpentinized dunites and Cretaceous and Tertiary igneous rocks (Figure 3) [10]. The area is crossed by abundant faults, including, towards the south of the valley, the Romeral fault system which was originally a subduction zone of the Pacific crust under the continent (Figure 3). Fission tracks datings obtained from volcanic zircons intercalated in alluvial and slope deposits suggest that the valley opening occurred about 2 Ma ago, probably due to tectonic activity. Since then it has endured the permanent action of erosive processes, which were probably enhanced by seismicity [11]. Medellin River is torrential in its upper course, as are all its tributaries. Average valley temperatures, which vary from $15^{\circ} \mathrm{C}$ to $22^{\circ} \mathrm{C}$ according to altitude and rainfall of 1500 to $3000 \mathrm{~mm}$ per year have fostered deep rock weathering, mass movements and flashfloods. The nature of soils varies with rock type and rainfall. The southern part of the valley is covered by a one meter thick volcanic ash layer, which also appears in the upper parts of the slopes and in the surrounding plateaus. These ashes were produced by several eruptions of the Ruiz Tolima massif, located $150 \mathrm{~km}$ south [12]. The original vegetation of the valley consisted of Andean forest, which covered the entire area excepting the steepest slopes and the marshy areas in the bottom of the valley [13].

\section{Spanish Arrival}

When the Spaniards coming from Peru reached the Aburra Valley (the Indian name of the locality) in 1541, they only found few scattered groups of natives. Chroniclers report "remnants of large buildings" and "stone trails", which would indicate a larger population with higher cultural standards. They also found gold (in graves, as elaborated jewels) and salt exploitations from natural brines pouring from several sources. The same year, after

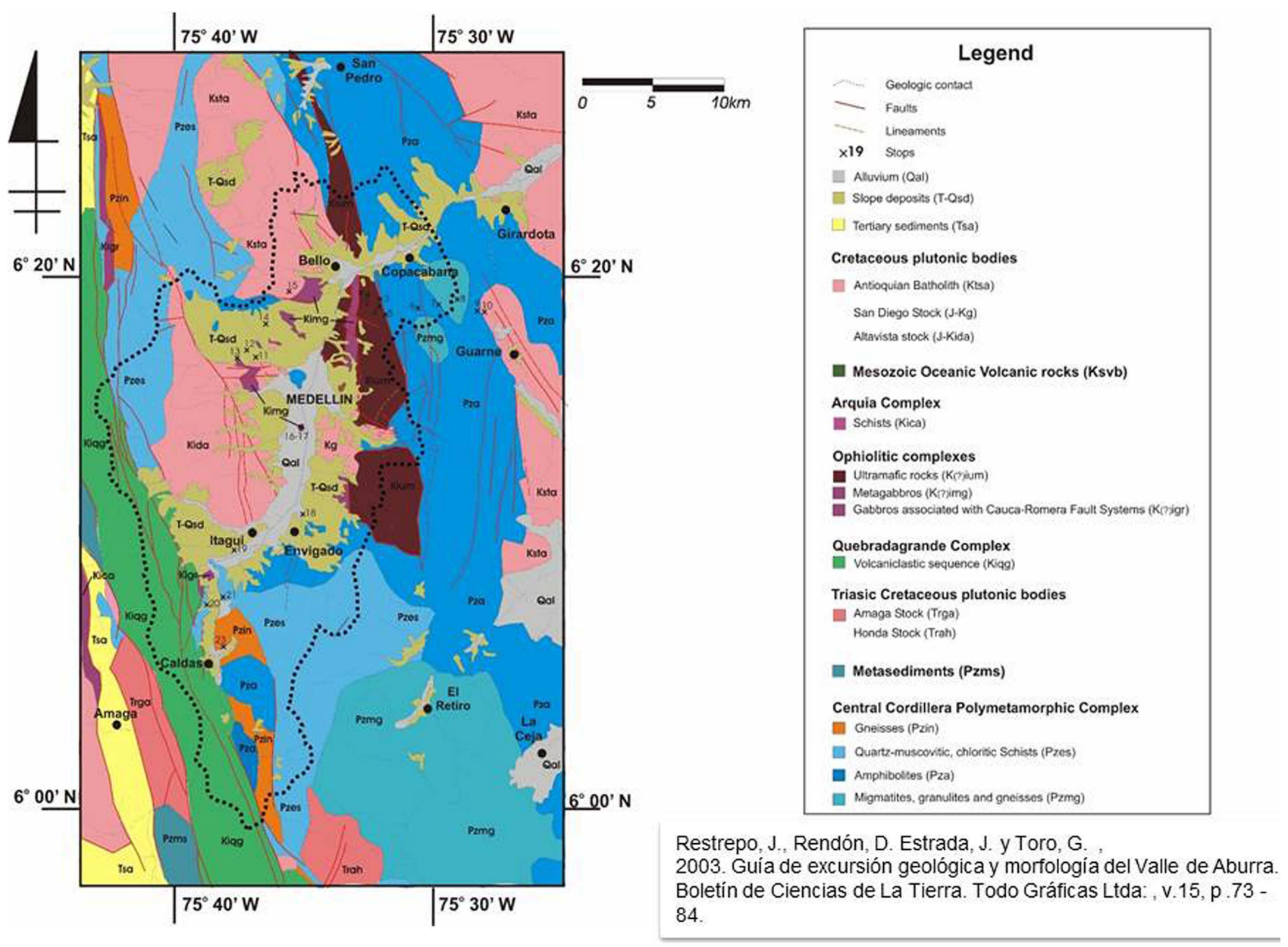

Figure 3. Geological map of the Medellin region. 


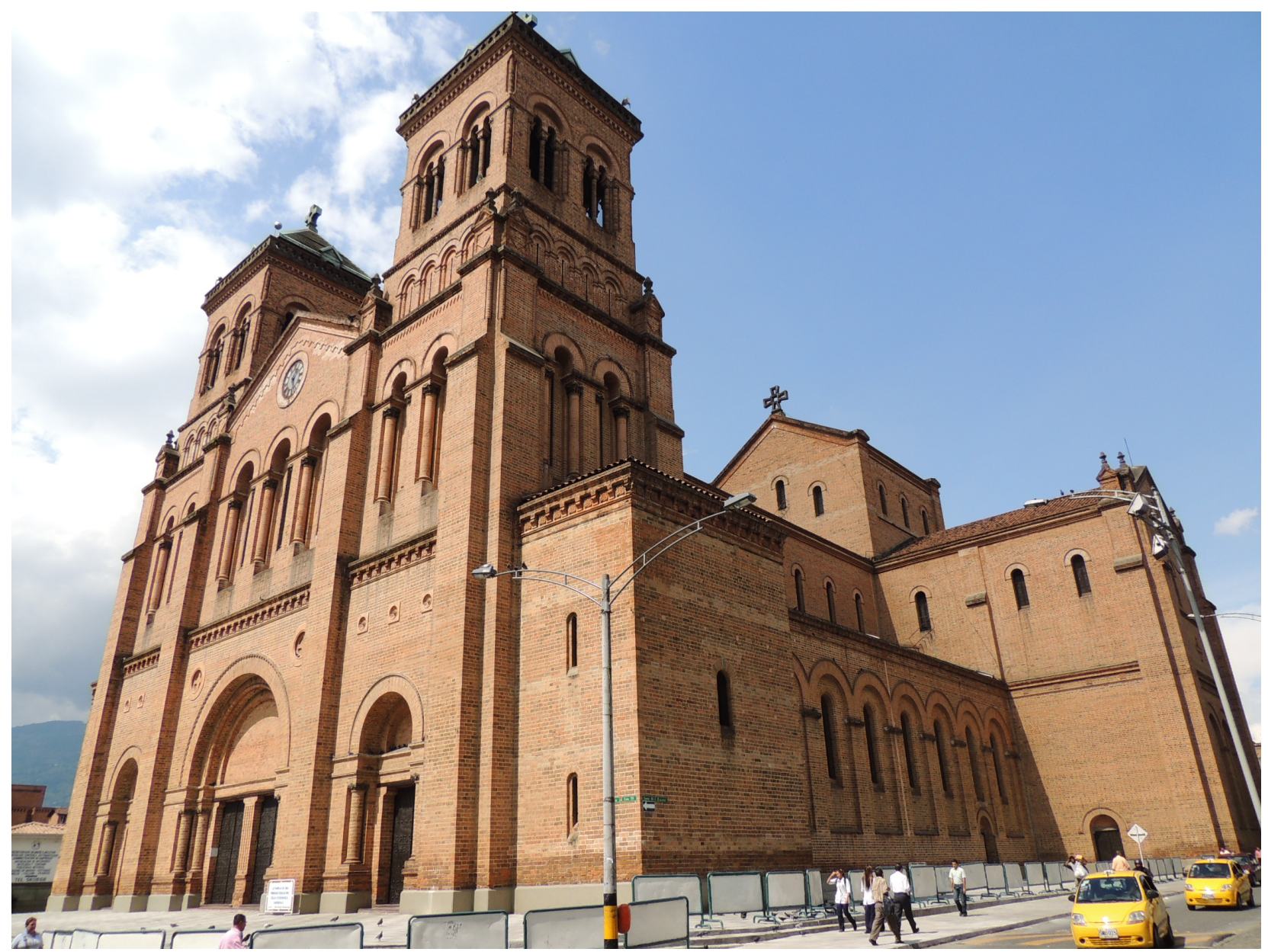

Figure 4. Medellin cathedral, one of the largest brick buildings in the world.

several intents, the town of Santa Fede Antioquia was founded at the foot of Western Cordillera, on the western bank of the Cauca river. Its main objective was to be the center of several mining camps located in the Western Cordillera and downstream the Cauca River. Santa Fe is located in a dry canyon with scarce cultivable areas and its agricultural prospects are thus quite limited.

\section{Colonial Times}

Since the beginning of $17^{\text {th }}$ century, Spaniards and mestizos established farms in the Aburra Valley: middle climate and fertile soils provided there good crops and were optimum for cattle raising. The number of inhabitants grew until they asked the Council of Indies to recognize their settlement as a "Villa", an autonomous township; this was strongly opposed by the Santa Fe people, who saw there a challenge to their city hegemony. Finally, the recognition was given in 1675 , and the new town took the name of Medellin, to honor a member of the Spanish Council of Indies [14]. At that time, the population of the Aburra Valley was of 288 families $(21.5 \%$ whites, $67.7 \%$ mestizos and mulatoes, $10.8 \%$ Indians). At the end of $18^{\text {th }}$ century, the number of inhabitants totaled 14,500 . Medellin commerce was boosted by the opening of two more gold fields in its surroundings. The economic activity of the small town was distributed among agriculture and cattle raising, commerce and mining, the latter mainly carried out by slave labor, sometimes as a part time activity due to the seasonal availability of water to exploit gold placers $[2,8]$. The prosperity and growth of Medellin were mainly supported at that time by agricultural activity, which permitted fruitful exchange and commerce with the surrounding areas. This sounds paradoxi$\mathrm{cal}$, since at the present time the same area contains about $70 \%$ (3.5 M inhabitants) of the population of the entire province. In spite of its growth, the town retained much of its rural characteristics. A census carried out in 1786 signals that from the existing earth-walled houses, 87 had thatch roofs and only 15 were covered with tiles. This also means that clay exploitation in order to produce tiles had already started at that time in the valley [15].

\section{6. $19^{\text {th }}$ Century and Present Time}

The village kept growing in size and wealth in spite of 
economic havoc caused by the independence wars and later by several civil wars. The urban expansion included houses, churches and other public constructions, and forced the adoption of building materials of better quality like bricks (Figure 4), which where obtained from surrounding clay deposits and also other weathered rocks, like dunite derived laterite. The Medellin River was deflected in the southern part of the valley in order to exploit alluvial gold [1]. Urban growth pushed crops and pasture toward the upper slopes of the valley. Another unexpected consequence was the impossibility, in the middle of $20^{\text {th }}$ century, to exploit an iron ore lateritic deposit in the eastern slope of the valley. When investors succeeded in rising out the funds necessary for the project, terrain prices due to urbanization had rendered it unfeasible. Many new buildings were erected and industry, particularly textile manufactures, was implanted. Simultaneously, the production of hydroelectrical energy started in several tributaries of the Medellin river through the building of dams in the upper part of their basins and of plants in the valley. Urbanization and road construction forced the canalization of the river, which used to meander in the middle of swampy lowlands. Another consequence was the covering of tributaries, thus transformed into streets.

Railways and roads were constructed, the city expanded and it consists at present of an almost complete conurbation which covers most of the valley (Figure 5); however, Medellin remains a relatively isolated locality in Colombia, excepting through the use of air transportation. The building of tunnels will somewhat improve this situation, but communication by road with sea harbors and other main cities remains an important problem.

\section{Natural Resources}

\subsection{Construction Materials}

The city consisted initially in thatched houses with earth walls, which meant that the materials were extracted in the same place where the house was built. A little more advanced stage was the use of adobe, which required extraction, drying and transportation. A further step was the adoption of bricks and tiles. These materials are still widely used in the Aburra Valley, with different degrees of modernization of the factories. Clays are exploited in the western slope of the valley; their sources are the wea-

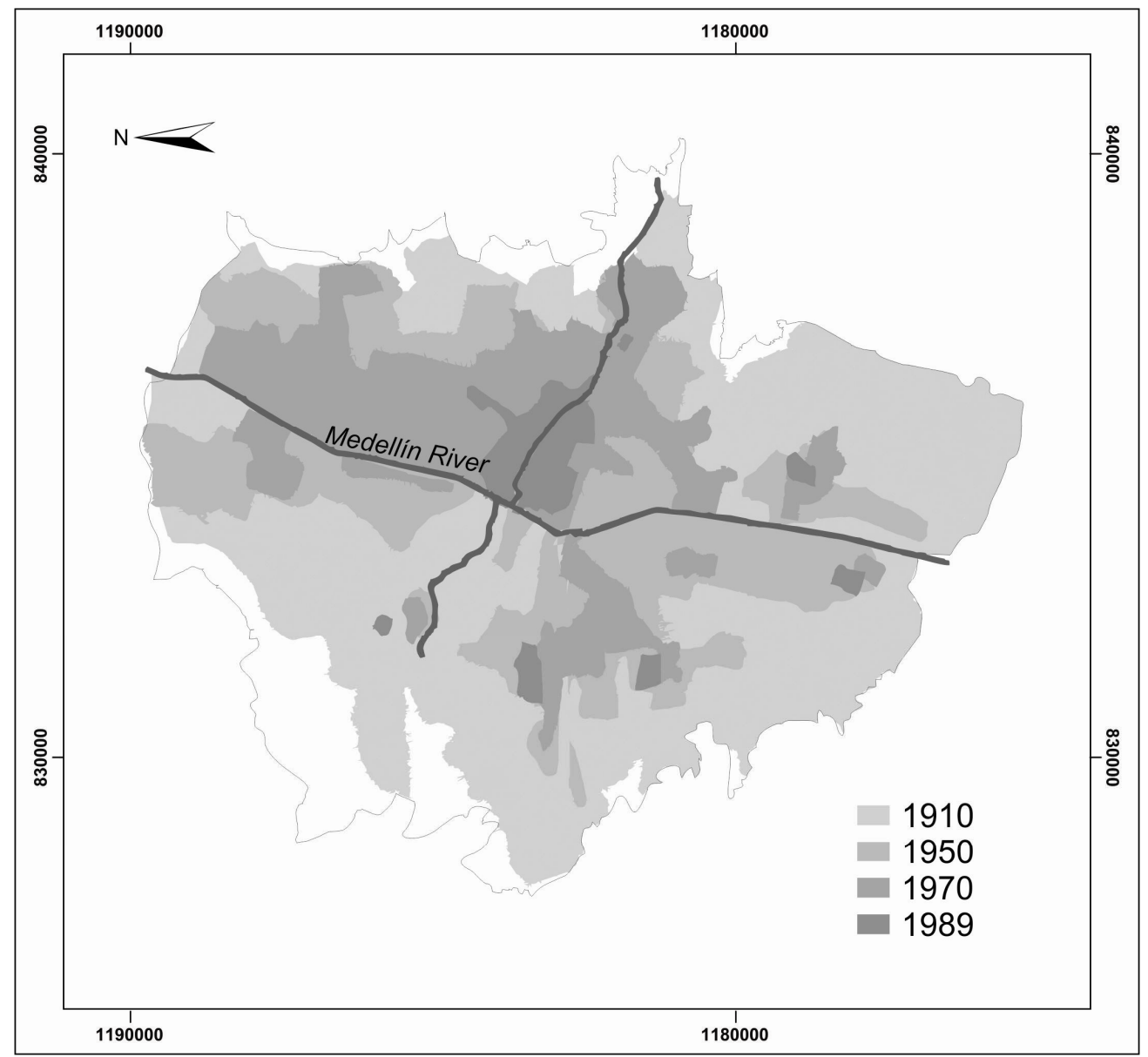

Figure 5. Medellin urban expansion. 
thered materials of a dioritic pluton [16].

Another important building material consists of "arenilla", a grey sand and clay material also produced by rock weathering, which is used with cement to prepare blocks. Aggregates are mined extensively in alluvial plains and also quarried from fractured rocks; the extraction of the alluvial deposits is carried out by direct excavation and simultaneous pumping of infiltrated waters down to depths reaching $50 \mathrm{~m}$. When exploitation ceases, water table rises and the hole becomes a deep lake filled with contaminated water. This problem has received no solution until now and jeopardizes the availability of valuable level terrains, already quite scarce in the valley (Figure 6).

In some places of the valley, material extraction has completely leveled hills and changed the landscape. Estimated approximate reserves of building materials in the Aburra Valley were given by Ramirez \& Caballero [17] at follows:

Sand: $19 \times 10^{6} \mathrm{~m}^{3}$

Aggregates: $48 \times 10^{6} \mathrm{~m}^{3}$

Clays: $3 \times 10^{6} \mathrm{~m}^{3}$

\subsection{Other Natural Resources}

Water supply is guaranteed through the capture of several streams, mostly independent of the Medellin river upper basin: the Metropolitan Area has a demand of $9 \mathrm{~m}^{3} \cdot \mathrm{s}^{-1}$ and an installed capacity of more than $17 \mathrm{~m}^{3} \cdot \mathrm{s}^{-1}$, of which less than 10\% comes from Medellin River upper tributaries. Scarcity of land suitable for urbanization and even for road construction is now felt acutely in the Aburra valley. Steep slopes and unstable soils were not an obstacle for illegal squatters who settled in the upper part of the valley in areas now recognized as highly exposed to risks. Invaders also built slums along rivers banks prone to flash floods. Relocation of part of this population have obliged the municipal government to develop original solutions: high rise buildings, constructed even in areas where surficial mass movements would prohibit the construction of single houses, but where stability is now controlled by appropriate deep foundations. The destruction of soil and vegetation have obvious consequences on the hydrological behavior of the earth surface: urbanization means zero infiltration, an increase in runoff and a decrease in evapotranspiration, which signify smaller lag times and higher peak discharges; these results have signified enhanced hydrologic hazards.

\section{Human Impacts}

Besides material extraction and soil destruction, human impacts include surface water contamination, which is presently corrected partially by a treatment plant; another one is under construction. Atmospheric pollution is quite high in several parts of the city, due mainly to mobile sources, estimated in $9 \mathrm{~m} \cdot$ tons $\cdot \mathrm{a}^{-1}$ of particulate materials [18] and industry, but is also favored by a partial tem-

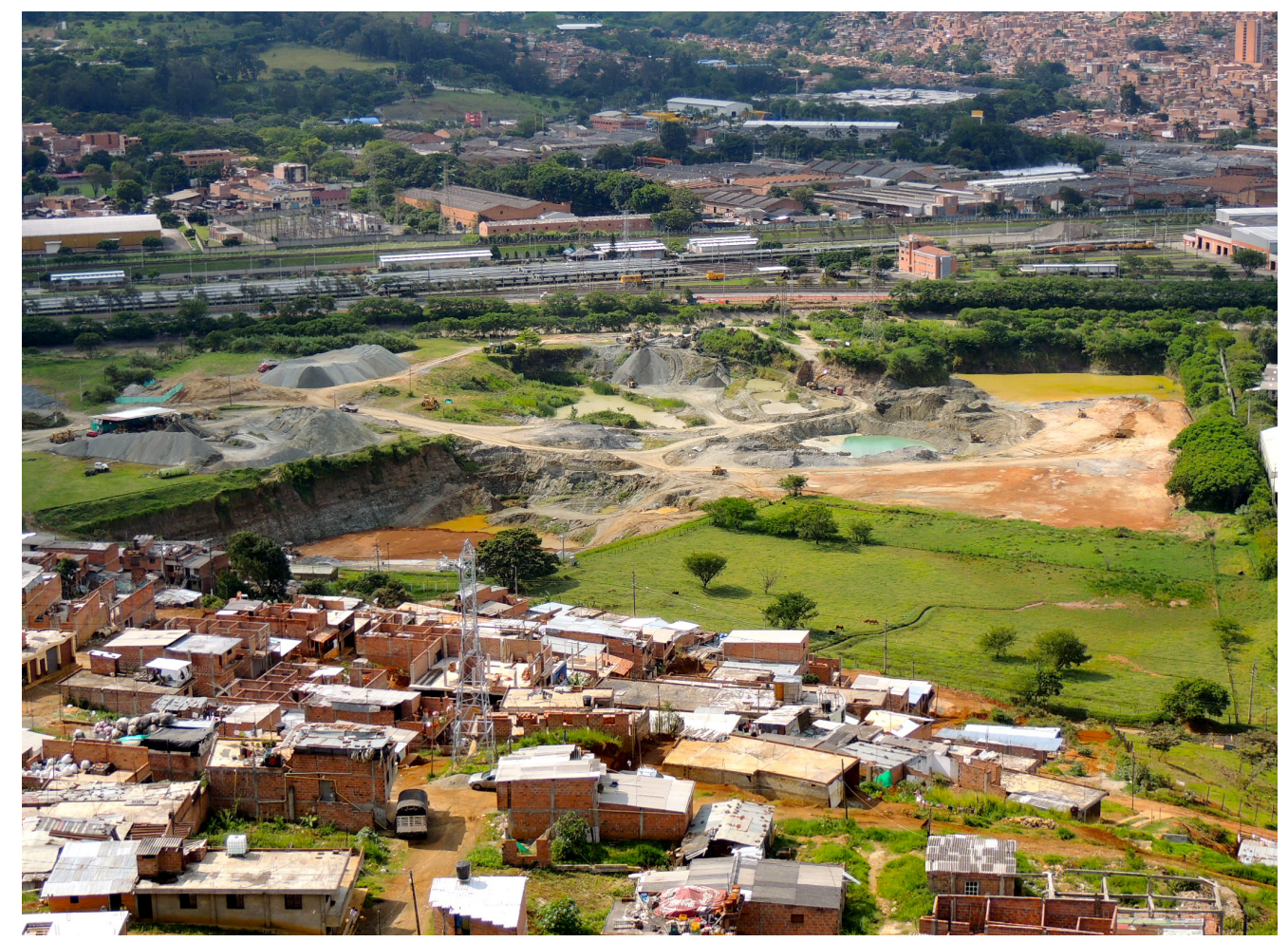

Figure 6. Mining of alluvial aggregates in the Aburra Valley. 
perature inversion which occurs in the valley during the warming hours. Total atmospheric emissions are given in Table 1 and a comparison with several other cities is shown in Figure 7.

Furthermore, about 2400 tons of solid garbage are presently produced daily in the Aburra valley. Thirty years ago they were deposited in the river flood plain and formed an artificial hill which was later occupied by illegal settlers (Figure 8). Due to health problems, inhabitants have been relocated. Garbage is now disposed in a sanitary landfill located at about $40 \mathrm{~km}$ from the center of Medellin. The ecological footprint of the Aburra community is 2.6 ha per inhabitant, (higher than Colombian's average: 1.9 ha per capita) which multiplied by a total population if about $3.0 \mathrm{M}$ inhabitants give a surface about 66 times the real size of the valley [19]. The present per capita water consumption is 63 liters and most is extracted from outside of the Aburra Valley watershed. The present average Medellin River flow is 32.8 liters, which would only supply the needs of 45,000 inhabitants. Finally, the calculated forest area necessary to absorb the carbon dioxide produced in the valley would be about 726,000 ha, a surface 6 times larger than the valley.

\section{Discussion}

Three and a half centuries ago, availability of natural resources was certainly a very good reason to explain the foundation of Medellin: a healthy climate, a locality well endowed in fertile soils propitious for crops and cattle raising and the vicinity of gold mine fields eager to consume what the valley produced. Although mining suffered several declines since that time and agriculture was progressively replaced by urbanization, the city retained its commercial vocation. Accumulation of capital and implantation of industry since the beginning of $20^{\text {th }}$ century completed the evolution. Abundant and relatively inexpensive hydroelectric power contributed to competetiveness. Building materials extraction in the valley is still important but it has become almost a nuisance for communities. Despite its remote and isolated location in the middle of mountains, with no navigable rivers, railroads and roads replaced mule trails and enabled the importation of raw materials and the exportation of manufactured goods, in spite of Twinam's [20] realistic observation: "In many ways, Antioquia was a poorly suitable region for industrialization".

The ideal human occupancy of the valley was proba-

Table 1. Total atmospheric emission in the Aburra Valley. Data from AMVA-UPB,2009[18]

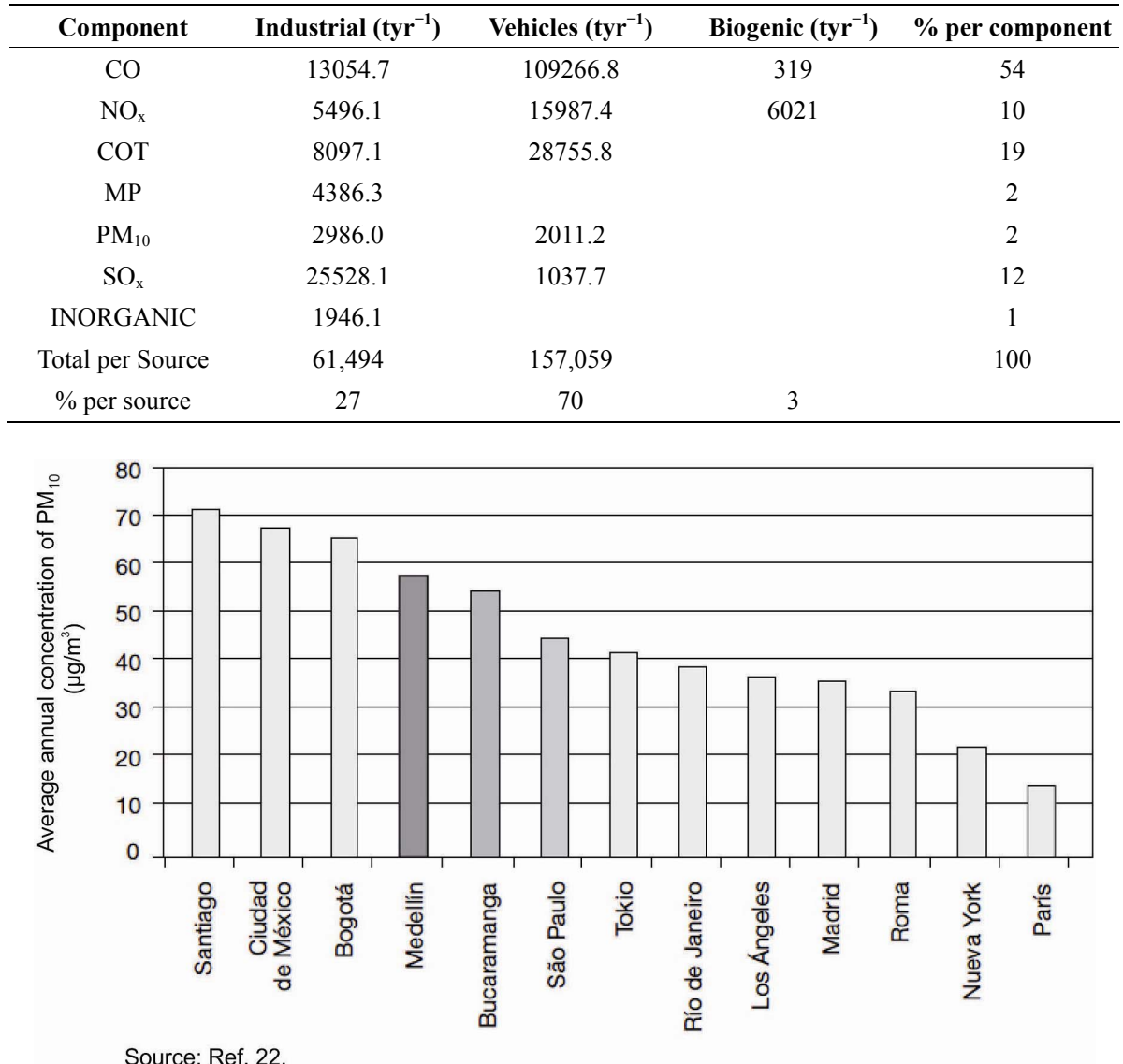

Figure 7. Average annual concentration of PM10 in selected cities. 


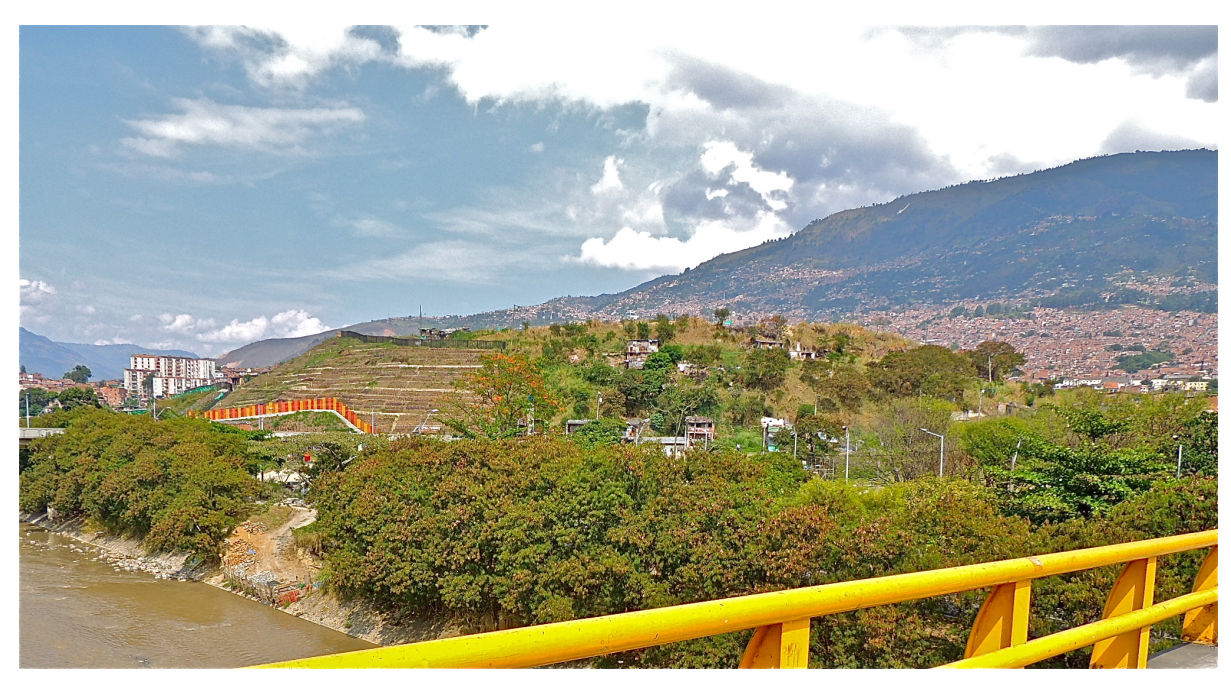

Figure 8. Abandoned garbage deposit which was occupied by illegal housing, now.

bly at the middle of $20^{\text {th }}$ century, when the population reached about 500,000 inhabitants. The present population is more than $3.5 \mathrm{M}$. Services and industry have replaced agriculture, which is now limited to very specific areas in the valley, and industry itself is moving to the surrounding regions. In spite of local government fragmentation (the valley is divided to into 10 independent municipalities), important efforts have been carried out to improve the living standards of the population: metropolitan train and cable cars, cultural centers, public libraries and high quality public schools, high schools and universities. In the next decades, Medellin's situation with respect to natural resource supplies will probably not be an excessive concern for water and energy. Building materials will probably have to be brought from farther places, as will raw materials used for the local industries. These transfers will become much easier when the projected highways connecting the Aburra valley with the other Colombian regions will be carried out. Improving living standards of the population through reduction of natural risks and pollution, enhancement of public transportation and land occupancy, and fostering a more equitable society are future tasks which should be undertaken by means of long term planning supported by democratic elections [21,22], but these aspects of development exceed the aims of the present paper.

\section{Conclusion}

In conclusion, the initial growth of Medellin was due to initial natural resources which have already disappeared almost completely. The challenge of the city inhabitants now is to generate human and economic resources that will eventually permit its future sustainable development. Meanwhile, speculations are still going on about the real factors that made Medellin the second city of the country in population and wealth, despite its modest and late ori- gin.

\section{REFERENCES}

[1] J. J. Parsons., "Antioqueño Colonization in Western Colombia," University of California Press, Berkeley, 1994, $212 \mathrm{p}$.

[2] B, Patiño, "Wealth, Poverty and Social Differenciation in the Antioquia Province during 16th Century (in Spanish)," Universidad de Antioquia, Clio, 2011, 281p.

[3] J. Diamond, "Guns, Germs and Steel. The Fates of Human Societies," W.W. Norton \& Company, New York, London, 1997.

[4] G. Reichel-Dolmatoff, "Indigenous Colombia, Prehispanic Period (in Spanish)," In: Nueva Historia de Colombia, Vol. 1, Colombia Indígena, Conquista y Colonia, Bogotá, Editorial Planeta, 1989, pp. 27-68.

[5] J. Aprile-Gniset, "The Colombian City Prehispanic, Conquest and Indian (in Spanish)," Biblioteca Banco Popular, Vol. 1, 1991, 568 p.

[6] C. O. Sauer, "The Early Spanish," Main University of California Press, Berkely, 1969, 306 p.

[7] J. Friede, "Territory Conquest and Human Settlement (in Spanish)," In: Nueva Historia de Colombia, Vol. 1, Colombia indígena, Conquista y Colonia, Bogotá, Editorial Planeta, 1989, pp. 69-115

[8] R. C. West, "Colonial Placer Mining in Colombia," Louisiana State University, 1952, 159 p.

[9] G. Botero, "Contribution to the Geology of Antiquia's Central Zone (in Spanish)," Anales de la Facultad de Mina, Medellín, No. 57, 1963, 101 p.

[10] Ingeominas, "Geologic Map of the Antioquia Department, scale 1:400 000 (in Spanish)," Memoria Explicativa, Medellín. Servicio Geológico Nacional, 2001, 240 p.

[11] G. Toro and M. Hermelin, "Stratigraphy of Volcanic Ashes from South Antioquia, Colombia: Possible Climatic Implications," Quaternary of South America and Antartic Peninsula, Vol. 8, 1991, pp. 201-217. 
[12] G. E. Toro, M. Hermelin, E. Schwabe, M. P. Posada, D. Silva. And G. Poupeau, "Fission Track Dating and Geomorphic Evidence for Long Term Stability in the Central Cordillera Highlands, Colombia," Zeitschrift fur Geomorphologie, Supplement Band, 2006, p. 1-16.

[13] C. Pérez, "The Aburra Valley Ecosystems, Past, Present and Future (in Spanish)," Memorias, Seminario "Una mirada a Medellín y al valle de Aburrá", Medellín: Universidad Nacional, Biblioteca Pública Piloto, Consejería Presidencia para Medellín y su Área Metropolitana, Alcaldía de Medellín, 1993, pp. 63-104.

[14] V. Álvarez, "Population and Settlement in the Aburra Valley, 1541-1951 (in Spanish)," Historia de Medellín, Compañía Suramericana de Seguros, 1996, pp. 57-84.

[15] J. A. Benítez, The Medellin's "carnero", R. L. Jaramillo, Editor Ediciones Autores Antioqueños, Medellín, 1988, $440 \mathrm{p}$.

[16] M. Hermelin, "Human Impact," In: M. Hermelin, A. Echeverry and J. Giraldo, Eds., Environment Urbanism Society, Medellin. E-Book Edited by Universidad EAFIT, 2011.

[17] M. I. Ramírez and H. Caballero, "Sustainability of the Exploitation of Building Materials in the Aburra Valley (in Spanish)," Proyecto de Grado, Ingeniería Geológica, Facultad de Minas, Universidad Nacional, Medellín, 2008.

[18] Metropolitana-Universidad Pontificia Bolivariana, Special Simulations, Task No. 1: Optimization of the Atmospheric Emission Inventory (in Spanish). Convenio de Asociación 543 de 2008, Acta No. 3, 2009, p. 121

[19] L. C. Agudelo, "Sustainability Indicatorsand Land Use Planning. Ecological Footprint and Strategic Ecosystems in Medellin, Colombia (in Spanish)," Región, Ciudad y Áreas Protegidas. FESCOL/CEREC, Bogotá, 2005, 24 p.

[20] A. Twinam, "Miners, Merchants and Farmers: The Roots of the Antioquian Business Spirit, 1763-1810 (in Spanish)," FAES, Biblioteca Colombiana de Ciencias Sociales, Medellín, 1985, $252 \mathrm{p}$.

[21] N. Matthieu and Y. Guermond, "The Sustainable City, from Politics to Science (in French)," Editions Quae. Dialogues, 2011.

[22] E. Sanchez-Triana, K. Ahmed and Y. Awe, "Prioridades Ambientales Para la Reducción de la Pobreza en Colombia," Un Análisis Ambiental del País Para Col- ombia (in Spanish). Banco Mundial, Mayorl Ediciones, Washington, 2008, 498 p. 